\title{
Determination of the Activity Signature of Key Carbohydrate Metabolism Enzymes in Phenolic-rich Grapevine Tissues
}

\section{Elizabeth Dunn Covington, ${ }^{1}$ Thomas Roitsch ${ }^{2,3}$ and Marina Dermastiaa ${ }^{1, *}$}

\author{
${ }^{1}$ National Institute of Biology, Večna pot 111, SI-1000 Ljubljana, Slovenia \\ ${ }^{2}$ Department of Plant and Environmental Sciences, Copenhagen Plant Science Centre, University of Copenhagen, \\ Højbakkegård Allé 13, 2630 Taastrup, Denmark \\ ${ }^{3}$ Global Change Research Centre, Czech Globe AS CR, v.v.i., Drásov 470, Cz-664 24 Drásov, Czech Republic \\ * Corresponding author: E-mail: marina.dermastia@ nib.si
}

Received: 04-14-2016

\begin{abstract}
Physiological studies in plants often require enzyme extraction from tissues containing high concentrations of phenols and polyphenols. Unless removed or neutralized, such compounds may hinder extraction, inactivate enzymes, and interfere with enzyme detection. The following protocol for activity assays for enzymes of primary carbohydrate metabolism, while based on our recently published one for quantitative measurement of activities using coupled spectrophotometric assays in a 96-well format, is tailored to the complexities of phenolic- and anthocyanin-rich extracts from grapevine leaf. As a case study we applied the protocol to grapevine leaf samples infected with plant pathogenic bacteria 'Candidatus Phytoplasma solani', known to alter carbohydrate metabolism in grapevine. The described adaptations may be useful for determination of metabolic fingerprints for physiological phenotyping of other plant species with inherently high levels of phenolic compounds.
\end{abstract}

Keywords: AGPase, carbohydrates, invertases, sucrose synthase, panel of enzyme activity assays, phytoplasma.

\section{Introduction}

Carbohydrates are the main energy and carbon source for all organisms, and in plants are also important signaling factors. ${ }^{1}$ Therefore, proper regulation of their production, distribution, and allocation is essential for both plant development and plant responses to pathogens and abiotic stresses. Significant changes in carbohydrate metabolism are associated with development of disease symptoms on grapevine infected with phytoplasmas, ${ }^{2-4}$ the causal agents of important crop and fruit tree diseases, including phytoplasmal grapevine diseases. ${ }^{5}$ The changes of carbohydrate metabolism in grapevine infected with these phytopathogenic bacteria have been detected mainly as increased expression of genes encoding the key enzymes associated with carbohydrate production. However, the resulting enzyme activities are affected by a complex interplay of transcriptional, post-transcriptional, and post-translational regulatory mechanisms, and protein levels may not correlate directly with mRNA levels. ${ }^{6}$ Enzyme activities provide a better proxy for protein abundance in these cases. ${ }^{7}$ Enzyme activities appear to be robust markers of phenotype ${ }^{8}$ and are not necessarily correlated with metabolites. ${ }^{9}$ Therefore, along with other nonbiased approaches, such as hormone signatures, ${ }^{10}$ enzyme activity signatures are important parts of a multidimensional phenomics approach to understanding plant physiological responses, such as the altered carbohydrate metabolism of phytoplasma-infected plants, to external fluctuations. ${ }^{8}$

We have recently developed a universal protein extraction and fractionation method for determining activities of key carbohydrate metabolism enzymes from a wide variety of plant species. ${ }^{11}$ These published semi-highthroughput spectrophotometric assays for determination of primary carbohydrate metabolism enzymes from a single extraction ${ }^{11}$ failed when applied to grapevine leaves. 
The most likely reason is the high endogenous level of phenolic and anthocyanin compounds present in grapevine, the concentrations of which further increase during phytoplasma infection. ${ }^{12,13}$ By reacting indiscriminately, these compounds both inactivate enzymes and interfere with detection techniques. ${ }^{14}$ Although the exact mechanisms by which phenolic compounds react with enzymes are usually unknown and vary by plant extract, simple models suggest that polyphenols induce protein precipitation and aggregation. ${ }^{15}$ In the present work we have adapted our general assays ${ }^{11}$ for application in uninfected grapevine samples and those infected with the most widespread grapevine phytoplasma in Europe, 'Candidatus Phytoplasma solani' ${ }^{16}$

\section{Experimental}

Whole asymptomatic grapevine leaves and those with symptoms of infection with ' $\mathrm{Ca}$. P. solani' were sampled in a production vineyard of grapevine (Vitis vinifera L.) cv. 'Chardonnay' in the south-western part of Slovenia $\left(45^{\circ} 58 \mathrm{~N}, 13^{\circ} 32 \mathrm{E}\right)$. Each sampling of fully developed leaves from approximately the third to the fifth leaf from the end of the shoots, and $1 \mathrm{~m}$ to $2 \mathrm{~m}$ above the ground on the sunny side of the grapevines was performed in a single day, during the light period between 10:00 and 13:00 hours. ${ }^{17}$ Each leaf was tested for ' $\mathrm{Ca}$. P. solani' presence according to the detection system developed by Hren et al. ${ }^{18}$

Protocols were established for measuring the enzyme activities of ADP-glucose pyrophosphorylase (AGPase), which is a rate-limiting enzyme in starch biosynthesis ${ }^{19}$ sucrose synthase (SuSy), which catalyzes sucrose breakdown to UDP-glucose and fructose in planta ${ }^{20}$ and three invertase isoenzymes - cytoplasmic invertase with a neutral $\mathrm{pH}$ optimum (cytINV), acid-insoluble bound to the cell wall (cwINV), and acid-soluble localized in the vacuole (vacINV). The workflow for measuring the enzyme activities of AGPase, SuSy, cytINV, cwINV and

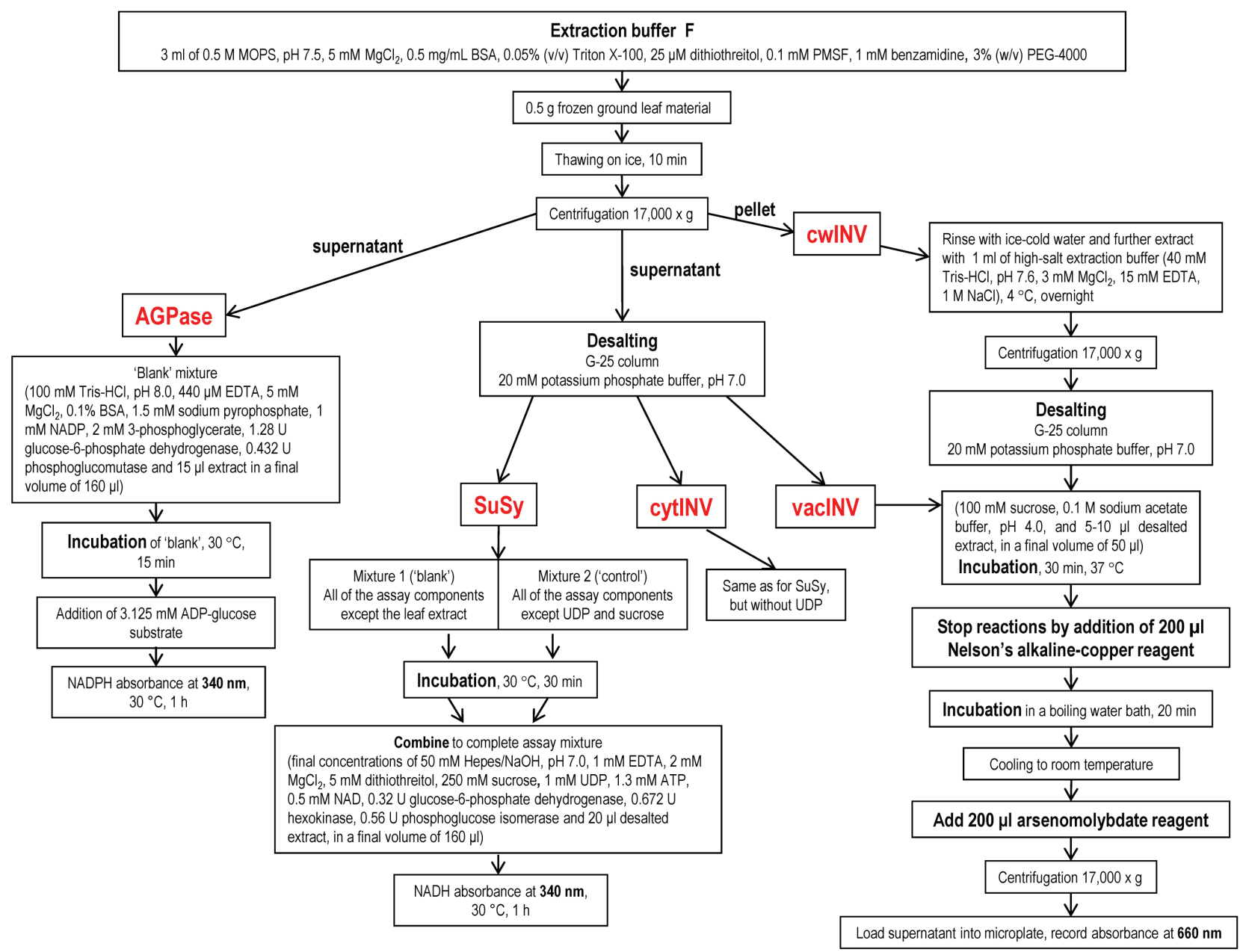

Figure 1. The workflow for measuring enzyme activities of AGPase, SuSy, cytINV, cwINV and vacINV. 
vacINV is depicted in the assays' scheme (Figure 1). Major changes to the original protocols ${ }^{11}$ were required, and these are detailed in the Results and Discussion section.

\section{Results and Discussion}

Although the method we established to determine an activity signature for key enzymes of carbohydrate metabolism performed well with various monocot and dicot model and crop plants ${ }^{11}$ and proved to be useful for physiological phenotyping, ${ }^{8}$ we encountered a number of difficulties in applying the "universal" extraction protocol to grapevine, probably due to interfering phenolic and anthocyanin compounds in the extracts..$^{12,13}$

\section{1. Adaptation of the Extraction Protocol for Grapevine}

Control measures for phenolics include polymeric reagents that are added to extraction buffers in order to bind secondary compounds released by cell lysis. Polyvinylpolypyrrolidone (PVPP) is frequently added to plant extracts to adsorb phenolics and has the advantage that it is insoluble, allowing it and adsorbed phenolics to be removed from the extract prior to analysis. However, when PVPP was added to grapevine leaf extracts, even at high concentrations $(2-30 \% \mathrm{w} / \mathrm{v})$, no invertase activity could be detected (Table 1). Additionally, when crude grapevine extract made with PVPP was added to the AGPase assay solution, a thick precipitate formed, preventing spectrophotometric measurement of AGPase activity. Past enzyme studies from grapevine leaf have instead used polyethylene glycol 4000 (PEG-4000) to bind phenolics. ${ }^{21-25}$ When varying concentrations of PEG-4000 were added to extraction buffer, the highest invertase activity was observed with 3\% (w/v) PEG-4000 (Table 1).

Four previously reported extraction buffers, including Jammer's extraction buffer $\mathrm{B}^{11}$ and three buffers used in grapevine enzyme studies, ${ }^{22,24,26}$ were tested in parallel for highest activities (see recipes in Table 2). Because activity of maize SuSy requires magnesium sulfate in extraction buffer, ${ }^{24}$ buffers were tested with and without added $\mathrm{Mg}$ if it was not included in the published recipe. For ease of comparison, the protease inhibitors PMSF and benzamidine were added to all extraction buffers. Additionally, 3\% (w/v) PEG-4000 was used to adsorb
Table 2. Extraction buffers tested for enzyme assays, modified from the indicated references.

\begin{tabular}{|c|c|c|}
\hline Buffer & Composition & Reference \\
\hline $\mathrm{A}$ & $\begin{array}{l}40 \mathrm{mM} \text { Tris-HCl, pH 7.6; } 1 \mathrm{mM} \text { EDTA; } \\
14 \mathrm{mM} \text { 2-mercaptoethanol; } 0.1 \mathrm{mM} \\
\text { PMSF; } 1 \mathrm{mM} \text { benzamidine; } 3 \%(\mathrm{w} / \mathrm{v}) \\
\text { PEG-4000 }\end{array}$ & 11 \\
\hline B & $\begin{array}{l}40 \mathrm{mM} \text { Tris-HCl, pH 7.6; } 1 \mathrm{mM} \text { EDTA; } \\
14 \mathrm{mM} \text { 2-mercaptoethanol; } 10 \mathrm{mM} \\
\mathrm{MgSO}_{4} ; 0.1 \mathrm{mM} \text { PMSF; } 1 \mathrm{mM} \\
\text { benzamidine; } 3 \% \text { (w/v) PEG-4000 }\end{array}$ & 11 \\
\hline $\mathrm{C}$ & $\begin{array}{l}250 \mathrm{mM} \text { MES-NaOH, pH 6.3; } 20 \mathrm{mM} \\
\text { cysteine-HCl; } 3 \text { mM EDTA; } 20 \mathrm{mM} \text { DTT; } \\
0.1 \mathrm{mM} \text { PMSF; } 1 \text { mM benzamidine; } 3 \% \\
\text { (w/v) PEG-4000 }\end{array}$ & 22 \\
\hline $\mathrm{D}$ & $\begin{array}{l}250 \mathrm{mM} \text { MES-NaOH, pH 6.3; } 20 \mathrm{mM} \\
\text { cysteine-HCl; } 3 \text { mM EDTA; } 20 \mathrm{mM} \text { DTT; } \\
10 \mathrm{mM} \mathrm{MgSO} \text {; } 0.1 \mathrm{mM} \text { PMSF; } 1 \mathrm{mM} \\
\text { benzamidine; } 3 \% \text { (w/v) PEG-4000 }\end{array}$ & 22 \\
\hline $\mathrm{E}$ & 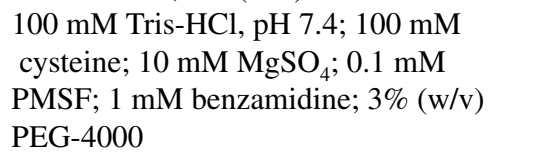 & 24 \\
\hline $\mathrm{F}$ & $\begin{array}{l}0.5 \mathrm{M} \text { MOPS, pH } 7.5 ; 5 \mathrm{mM} \mathrm{MgCl}_{2} \text {; } \\
0.5 \mathrm{mg} / \mathrm{ml} \text { BSA; } 0.05 \% \text { Triton X-100; } \\
25 \mu \mathrm{M} \text { DTT; } 0.1 \mathrm{mM} \text { PMSF; } 1 \mathrm{mM} \\
\text { benzamidine; } 3 \% \text { (w/v) PEG-4000 }\end{array}$ & 26 \\
\hline
\end{tabular}

polyphenols in all extraction buffers. Extraction buffer $\mathrm{F}^{26}$ gave the highest activity for all enzymes except cwINV (Figure 2), perhaps due to the additional phenol-binding capacity of bovine serum albumin (BSA).

High concentrations of endogenous substrates for SuSy and invertase necessitated desalting of crude extracts prior to enzyme assay. Desalting further serves to remove reducing agents and secondary compounds that may inhibit activity of invertase. Grapevine SuSy activity was greatly diminished when crude extracts were dialyzed overnight ( $0.21 \mathrm{nkat} / \mathrm{g} \mathrm{FW})$ as compared to column desalting (1.47 nkat/g FW). Additionally, grapevine extracts lost most SuSy activity if extracts were frozen (data not shown). Therefore, cleared extracts were desalted over a Sephadex G-25 column, and SuSy activity was assayed immediately. The final extraction protocol allowed measurement of five key enzymes of carbohydrate metabolism from a single extraction. AGPase, SuSy, and cytINV were assayed immediately on the day of enzyme extraction, while vacINV and cwINV could be assayed from frozen extracts at a later date.

Table 1. Specific activity (nkat/g FW) of vacINV in extraction buffer A (see Table 2) supplemented with the indicated concentration (w/v) of phenolic-binding agent. All extractions were performed on the same biological sample consisting of apical leaves pooled from a single plant, and measurements are mean values from duplicate measurements of the same extract.

\begin{tabular}{ccccccc}
\hline & 2\% PVPP & 10\% PVPP & 30\% PVPP & 1\% PEG-4000 & 3\% PEG-4000 & 6\% PEG-4000 \\
\hline Activity & 0 & 0 & 0 & 3.28 & 3.83 & 2.43 \\
\hline
\end{tabular}


a)

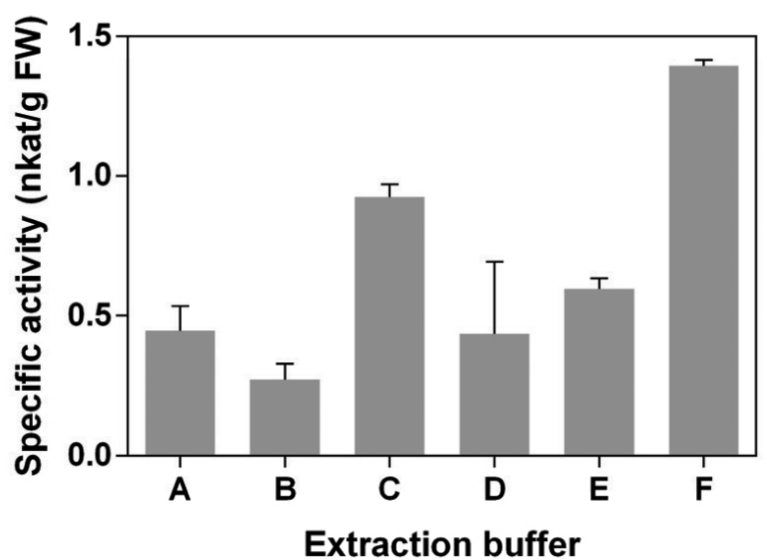

c)

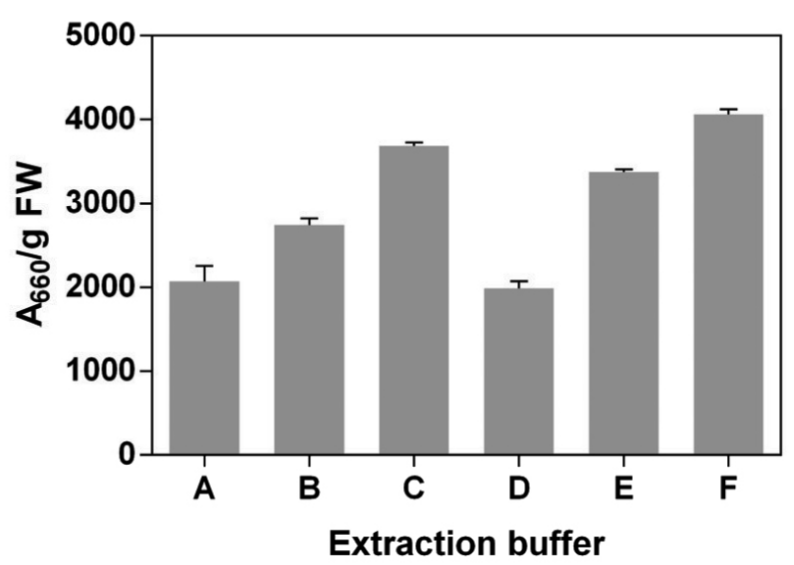

b)

SuSy

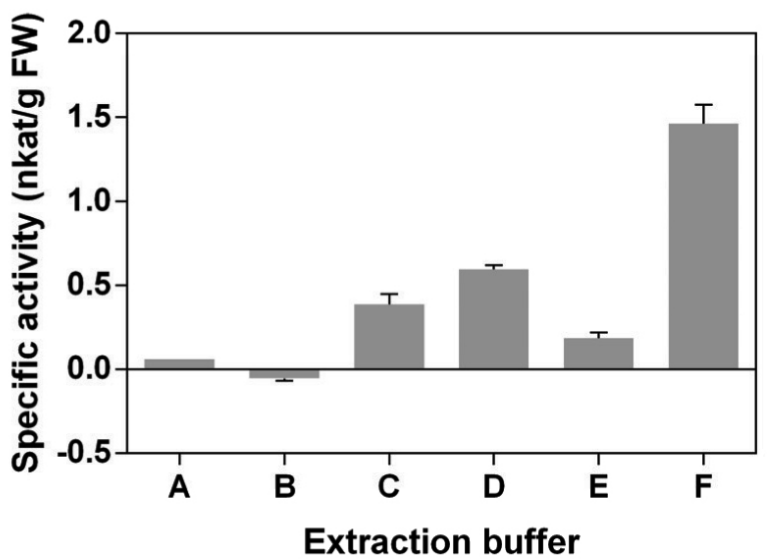

d)

Cell wall invertase

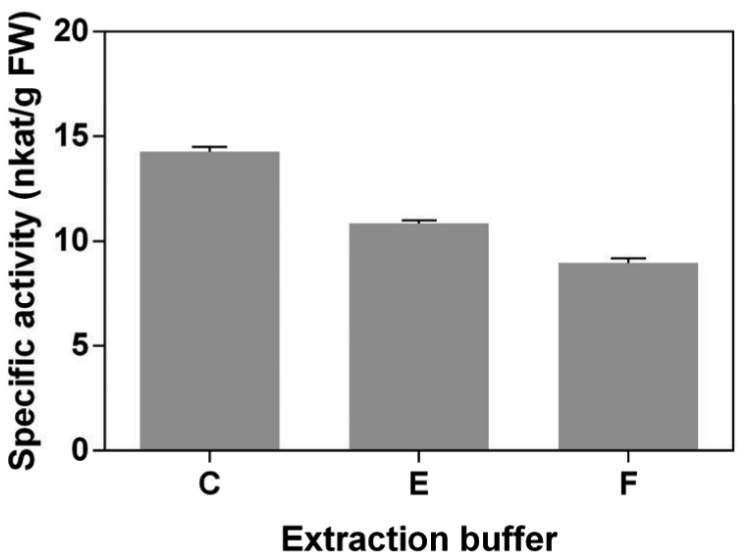

Figure 2. Enzyme activity of AGPase (a), SuSy (b), vacINV (c), and cwINV (d) obtained from various extraction buffers. All extractions were performed on the same biological sample consisting of apical leaves pooled from a single plant, and bars represent mean of three technical replicates. Error bars represent standard error of the mean (s.e.m.). Because the vacINV experiment lacked an appropriate standard curve, results are presented as absorbance values at $660 \mathrm{~nm}$ rather than as reducing sugar concentrations.

\section{2. Adaptation of Enzyme Activity Assays for Grapevine Samples}

Enzyme assay methods also had to be altered for grapevine leaf samples. The SuSy and AGPase assay conditions of Jammer et al. ${ }^{11}$ performed adequately for grapevine extracts with only slight modification. Both assays required pre-incubation for 15-30 minutes to allow run-down of background activity. In the case of SuSy, blank and control mixtures were separately pre-incubated to allow run-down of blank reactions due to extract and of control reactions due to contaminating sugars in the sucrose substrate.

Invertase assay proved more problematic in grapevine. ABTS (2,2'-azino-bis(3-ethylbenzothiazoline-6-sulfonic acid)) used for glucose detection ${ }^{11}$ reacts with phenolic compounds, ${ }^{27}$ and substrate-free blanks spiked with known concentrations of glucose reported inaccurate glucose levels when measured with glucose oxidase/peroxi-
dase/ABTS. A commercial glucose determination kit (Megazyme) also gave inaccurate measures; invertase continued to cleave sucrose at a slow rate after detection buffer was added, causing slow color development over a time course of hours rather than minutes. Therefore, we used the Nelson-Somogyi method ${ }^{28,29}$ to determine the reducing sugar products of the invertase reaction. This method had the advantage of quickly halting the invertase reaction at the end of incubation when samples were immersed in a boiling water bath, and tests of samples spiked with glucose gave values accurate within $8 \%$.

Other adaptations to the invertase assay included increasing the substrate concentration from $10 \mathrm{mM}$ to 100 $\mathrm{mM}$ because the reported $K_{\mathrm{M}}$ of grapevine vacINV is around 3-10 mM sucrose. ${ }^{30-32}$ VacINV activity was higher at $\mathrm{pH} 4.0$ than $\mathrm{pH} 4.5$ (7.8 nkat/g FW vs. $5.1 \mathrm{nkat} / \mathrm{g} \mathrm{FW}$; see also $^{22}$ ). Finally, the reaction progress was followed and found to be linear for at least 1 hour (Figure 3). For ef- 


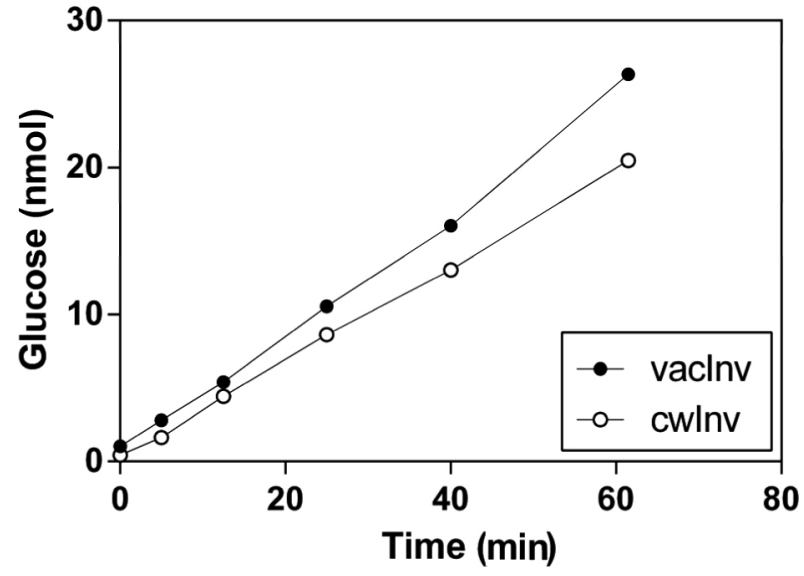

Figure 3. Time course of invertase reaction. Extraction was performed on apical leaves pooled from a single plant. Assays of vacINV and cwINV were allowed to proceed for 1 hour. Samples were removed at the indicated time points, and glucose accumulation immediately measured.

ficiency of measurement, therefore, the length of the assay incubation was reduced to 30 minutes, well within the linear portion of the reaction.

\section{3. Case study: Effect of Infection of Grapevine Leaves by Phytoplasma 'Ca. P. Solani'}

The developed protocol was tested on uninfected grapevine leaves and leaves infected with ' $\mathrm{Ca}$. P. solani' (Figure 4). The results show high activity of vacINV,

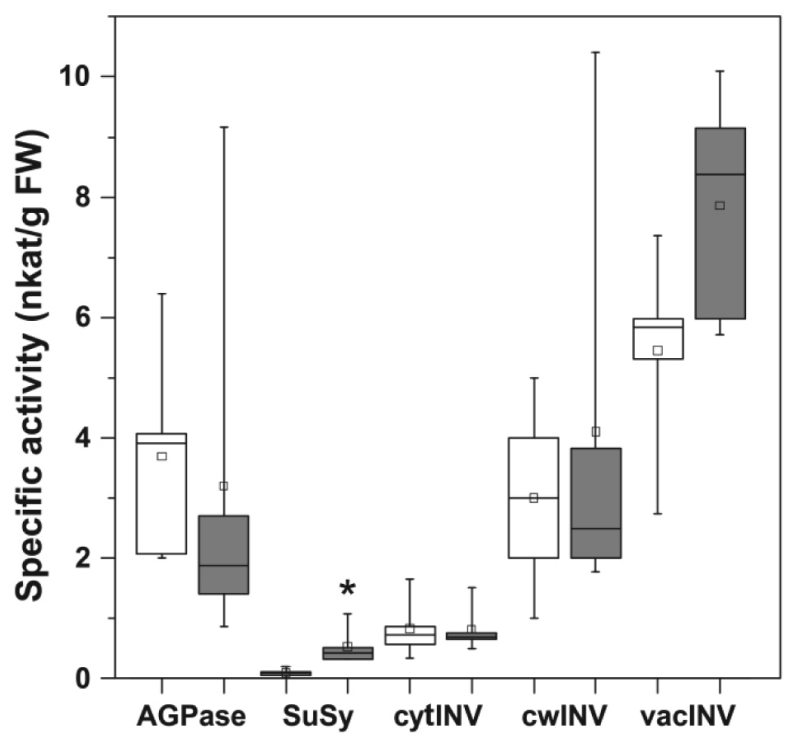

Figure 4. Box plot of the specific activities of AGPase, SuSy, cytINV, cwINV and vacINV in fully developed whole-leaf samples of uninfected (white boxes) and ' $\mathrm{Ca}$. P. solani'-infected (grey boxes) grapevines. Line across the box, median; square, mean of five biological replicates; box, $25^{\text {th }}$ and $75^{\text {th }}$ percentiles; whiskers, minimum and maximum values. *, $p<0.05$ (Student's $t$-tests). which was higher, although not significantly ( $p=0.07)$, in infected samples. The amount of transcript of VvINV2 encoding vacINV is increased in infected leaf veins. ${ }^{2}$ Activity of SuSy significantly increased (from 0.10 to 0.53 nkat/g FW), in correlation with the gene expression of $V v S u S y^{2}$ and similar observations from grapevine infected with another taxonomically unrelated phytoplasma, ${ }^{4}$ suggesting a specific role of SuSy in phytoplasma-infected grapevines.

In sum, the altered protocol, while based heavily on that of Jammer et al. ${ }^{11}$ is tailored to the complexities of phenolic-rich extracts from grapevine leaf. The described adaptations may be useful for other plant species with inherently high levels of phenolic compounds or tissues that are enriched in phenolics due to exogenous factors or expression of specific transgenes. ${ }^{33}$ This protocol provides a valuable platform for advanced metabolic fingerprinting of grapevine to complement determination of metabolites ${ }^{4,34-36}$ and will help narrow the knowledge gap between genome and phenotype in environment and agricultural management practice. $^{8}$

\section{Acknowledgement}

This work was supported by Javni sklad RS za razvoj kadrov in štipendije, visiting fellowship to EC, ARRS program P4-0165 and the Ministry of Education, Youth and Sports of CR within the National Sustainability Program I (NPU I), grant number LO1415 to TR.

\section{References}

1. Halford N. G., Curtis T. Y., Muttucumaru N., Postles J., Mottram D. S., Ann Appl Biol. 2011, 158(1), 1-25. http://dx.doi.org/10.1111/j.1744-7348.2010.00443.x

2. Hren M., Nikolić P., Rotter A., et al. BMC Genomics. 2009, 10(1), 460-476.

http://dx.doi.org/10.1186/1471-2164-10-460

3. Santi S., De Marco F., Polizzotto R., Grisan S., Musetti R., Front Plant Sci. 2013, 4,171.

http://dx.doi.org/10.3389/fpls.2013.00171

4. Prezelj N., Covington E., Roitsch T., et al. Front Plant Sci. 2016, 7, 711.

http://dx.doi.org/10.3389/fpls.2016.00711

5. Marcone C., Ann Appl Biol. 2014, 165, 199-221. http://dx.doi.org/10.1111/aab.12151

6. Maier T., Güell M., Serrano L., FEBS Lett. 2009, 583 (24). 3966-3973.

http://dx.doi.org/10.1016/j.febslet.2009.10.036

7. Stitt M, Gibon Y., Trends Plant Sci. 2014, 19(4), 256-265. http://dx.doi.org/10.1016/j.tplants.2013.11.003

8. Großkinsky D. K., Svensgaard J., Christensen S., Roitsch T., J Exp Bot. 2015, 66(18), 5429-5440.

http://dx.doi.org/10.1093/jxb/erv345 
9. Sulpice R., Trenkamp S., Steinfath M., et al. Plant Cell. 2010, 22(8), 2872-2893. http://dx.doi.org/10.1105/tpc.110.076653

10. Großkinsky D., K., Albacete A., Jammer A., et al. Mol Plant. 2014, 7(6), 1053-1056. http://dx.doi.org/10.1093/mp/ssu015

11. Jammer A., Gasperl A., Luschin-Ebengreuth N., et al. J Exp Bot. 2015, 66(18), 5531-5542. http://dx.doi.org/10.1093/jxb/erv228

12. Margaria P., Ferrandino A., Caciagli P., Kedrina O., Schubert A., Palmano S., Plant, Cell Environ. 2014, 37(9), 2183-2200 http://dx.doi.org/10.1111/pce.12332

13. Rusjan D., Veberič R., Mikulič-Petkovšek M., Eur J Plant Pathol. 2012, 133, 965-974. http://dx.doi.org/10.1007/s10658-012-9967-7

14. Loomis W., D., Methods Enzymol. 1974, 31, 528-544. http://dx.doi.org/10.1016/0076-6879(74)31057-9

15. Pierpoint W., S., Humana Press, 2003. Vol 244, pp. 65-74. http://dx.doi.org/10.1385/159259655X

16. Quaglino F., Zhao Y., Casati P., et al. Int J Syst Evol Microbiol. 2013, 63 (8), 2879-2894. http://dx.doi.org/10.1099/ijs.0.044750-0

17. Hren M, Nikolić P., Rotter A., et al. BMC Genomics. 2009, 10(1), 460. http://dx.doi.org/10.1186/1471-2164-10-460

18. Hren M, Boben J., Rotter A., Kralj P., Gruden K., Ravnikar M., Plant Pathol. 2007, 56(5), 785-796. http://dx.doi.org/10.1111/j.1365-3059.2007.01688.x

19. Ballicora M. A., Iglesias A. A., Preiss J. Photosynth Res. 2004, 79(1), 1-24. http://dx.doi.org/10.1023/B:PRES.0000011916.67519.58

20. Koch K., Curr Opin Plant Biol. 2004, 7(3), 235-246. http://dx.doi.org/10.1016/j.pbi.2004.03.014

21. Hunter J. J., Skrivan R., Ruffner H. P., Vitis. 1994, 33(4), $189-195$.

22. Ruffner H. P., Adler S, Rast D. M., Phytochemistry. 1990, 29 (7), 2083-2086.

http://dx.doi.org/10.1016/0031-9422(90)83009-P
23. Davies C., Robinson S. P., Plant Physiol. 1996, 111, 275-283. http://dx.doi.org/10.1104/pp.111.1.275

24. Claussen W, Loveys B. R,, Hawker J. S., Physiol Plant. 1985, 65, 275-280. http://dx.doi.org/10.1111/j.1399-3054.1985.tb02395.x

25. Downton W. J. S, Hawker J. S., Phytochemistry. 1973, 12(7), 1557-1563. http://dx.doi.org/10.1016/0031-9422(73)80367-X

26. Takayanagi T., Yokotsuka K., Am J Enol Vitic. 1997, 48(4), 403-407.

27. Walker R. B., Everette J. D., J Agric Food Chem. 2009, 57, 1156-1161. http://dx.doi.org/10.1021/jf8026765

28. Nelson N. A., J Biol Chem. 1944, 153, 375-380.

29. Somogyi M., J Biol Chem. 1952, 195, 19-23.

30. Nakanishi K., Wu W, Yokotsuka K. J Ferment Bioeng. 1991. 71(1), 66-68. http://dx.doi.org/10.1016/0922-338X(91)90306-2

31. Pan Q-H, Cao P., Duan C-Q., Aust J Grape Wine Res. 2009, 15(1), 9-17. http://dx.doi.org/10.1111/j.1755-0238.2008.00030.x

32. Porntaveewat W., Takayanagi T., Yokotsuka K., J Ferment Bioeng. 1994, 78(4), 288-292. http://dx.doi.org/10.1016/0922-338X(94)90359-X

33. Guivarc'h A., Rembur J., Goetz M., et al. J Exp Bot. 2002, 53(369), 621-629. http://dx.doi.org/10.1093/jexbot/53.369.621

34. Dai Z. W., Léon C., Feil R., Lunn J., Delrot S., Gomès E., $J$ Exp Bot. 2013, 5, 1345-1355. http://dx.doi.org/10.1093/jxb/ers396

35. Griesser M., Lawo N. C., Crespo-Martinez S., et al. Plant Sci. 2015, 234, 38-49. http://dx.doi.org/10.1016/j.plantsci.2015.02.002

36. Prezelj N., Fragner L., Weckwerth W., Dermastia M., Mitteilungen Klosterneubg Rebe und Wein, Obs und Früchteverwertung. 2016, 66(1), 74-78.

\section{Povzetek}

Pri fizioloških raziskavah rastlin moramo pogosto izolirati encime iz tkiv, v katerih so visoke koncentracije fenolov in polifenolov. Če teh spojin predhodno ne nevtraliziramo ali odstranimo, lahko ovirajo ekstrakcijo, deaktivirajo encime ali motijo njihovo detekcijo. Predstavljeni protokol merjenja aktivnosti encimov primarnega metabolizma ogljikovih hidratov temelji na našem pred kratkim objavljenem protokolu za kvantitativno hkratno spektrofotometrično merjenje encimskih aktivnosti v formatu testne ploščice s 96 vdolbinicami. Novi protokol je prirejen ekstraktom iz listov vinske trte, ki vsebujejo kompleksne fenole in antociane. Kot vzorčni primer smo novi protokol uporabili na vzorcih listov vinske trte, okuženih s patogeno bakterijo 'Candidatus Phytoplasma solani', ki spreminja metabolizem ogljikovih hidratov $\mathrm{v}$ vinski trti. Opisana prilagoditev protokola je uporabna za določanje metabolnih odtisov pri fizioloških fenotipizacijah različnih rastlinskih vrst, ki imajo visoko raven fenolnih spojin. 